\title{
Heterogeneity determination of bovine leukemia virus genome in Santa Catarina state, Brazil
}

\author{
Determinação da heterogeneidade do genoma do vírus da \\ leucose enzoótica bovina no estado de Santa Catarina, Brasil
}

\author{
Sheyla Michele Rodakiewicz ${ }^{*}$, Maria Luiza Fernandez', Maria Luiza Munhoz', Flávia Harumi Scheffer \\ Yamakawa', Monica Urio', Fabiana Forell', Sandra Ferraz', Vagner Miranda Portes' ${ }^{2}$, Ubirajara Maciel da Costa'
}

\begin{abstract}
Bovine leukemia virus (BLV) is a member of Retroviridae family, genus Deltaretrovirus, and the main viral agent responsible for economic loses in dairy herds. Some studies have been carried out about BLV genotypes, and at least seven genotypes were found out in samples of different regions of the world. The objective of this study was to identify BLV samples from seropositive dairy cattle in Santa Catarina state, Brazil, using molecular techniques. Blood samples were collected (454) from dairy cattle from 31 different farms, and serology using agar gel immunodiffusion test (AGID) was performed. After that, 191 seropositive samples were submitted to DNA extraction, and in 77 samples the polymerase chain reaction (PCR) for amplification of a $440 \mathrm{bp}$ fragment of the env gene was performed. Nineteen DNA samples were subjected to restriction fragment length polymorphism (RFLP) analysis by digestion of the PCR fragment by five restriction endonucleases - BamHI, HaeIII, Tru9I, TaqI, and MwoI. It was found $42 \%$ seropositive animals $(191 / 454)$ and $68 \%$ positives of the farms (21/31). The PCR showed $80.5 \%$ (62/77) of animals positive. The RFLP analysis identified five different genotypes dispersed by Santa Catarina state, with the highest prevalence for genotype X (47.4\%). Overall, our results identified the viral genotypes present in dairy cattle and the prevalence of new variants in representative farms from Santa Catarina state.
\end{abstract}

KEYWORDS: Bovine leukemia virus, Deltaretrovirus, dairy cattle, $e n v$, restriction fragment length polymorphism.
RESUMO: O bovine leukemia virus (BLV) é um membro da família Retroviridae, gênero Deltaretrovirus, e o principal agente viral causador de perdas econômicas em rebanhos leiteiros. Diversos estudos têm sido feitos sobre os genótipos de BLV, e foram encontrados pelo menos sete em amostras de diferentes partes do mundo. O objetivo deste estudo foi realizar a caracterização molecular de amostras de BLV de bovinos leiteiros soropositivos no estado de Santa Catarina. Foram coletadas 454 amostras de sangue de bovinos de 31 propriedades, e fez-se inicialmente a sorologia por meio do teste de imunodifusão em gel de ágar. Após a sorologia, 191 amostras soropositivas foram então submetidas à extração de DNA, e em 77 amostras se realizou a reação da polimerase em cadeia (PCR), para a amplificação de um fragmento de $440 \mathrm{pb}$ do gene $e n v$. Dezenove amostras foram submetidas à análise do polimorfismo dos fragmentos de restrição por digestáo do fragmento da PCR por cinco enzimas de restrição: BamHI, HaeIII, Tru9I, TaqI e MwoI. Os resultados obtidos na sorologia apontaram $42 \%$ de animais soropositivos (191/454) e $68 \%$ de propriedades positivas (21/31). Na PCR, 80,52\% (62/77) dos animais apresentaram-se positivos. A análise do polimorfismo dos fragmentos de restrição identificou cinco genótipos circulantes no estado, e a maior prevalência foi observada no genótipo $\mathrm{X}$ $(47,4 \%)$. Este estudo permite-nos conhecer alguns dos genótipos virais presentes em bovinos leiteiros do estado de Santa Catarina, bem como identificar a existência de novas variantes e sua prevalência atual, e os resultados são úteis para futuros estudos epidemiológicos.

PALAVRAS-CHAVE: Bovine leukemia virus; Deltaretrovirus; bovinos leiteiros; env; polimorfismo dos fragmentos de restrição.

'Universidade do Estado de Santa Catarina - Campus III Planalto Serrano - Lages (SC), Brazil

${ }^{2}$ Empresa de Pesquisa Agropecuária e Extensão Rural de Santa Catarina (Epagri) - Chapecó (SC), Brazil

*Corresponding author: sheyla_mi@hotmail.com

Received on: 09/29/2016. Accepted on: 05/04/2018

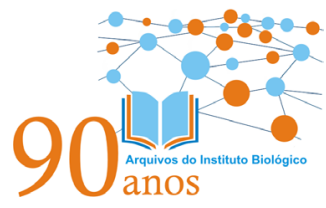




\section{INTRODUCTION}

Bovine leukemia virus (BLV) is the causative agent of enzootic bovine leukosis, a disease of global distribution, and its prevalence varies widely among cattle herds, being higher in dairy cattle. Thirty percent of the infected animals may develop persistent lymphocytosis (PL), an increase of circulating lymphocytes, in this case B cells, and only 2 to $5 \%$ may develop lymphosarcomas (LEUZZI JR. et al., 2001).

$\mathrm{BLV}$ is a member of the genus Deltaretrovirus, from Retroviridae family, presenting similarities with the human T-lymphotrophic virus type- 1 and 2 (TOSTES, 2005). The virus genome consists of two single strand RNA molecules with positive polarity, being more prone to mutations than viruses with a DNA genome (CANN, 2005). Most of the mutations are punctual and occur in nucleotide sequences, which may lead to amino acid substitutions of the glycoprotein surface (RODRIGUEZ et al., 2009).

The identification of nucleotide mutations can be performed by restriction fragment length polymorphism (RFLP) analysis. This technique is based on genotyping by partial genome sequence, and has been widely used because it gives an idea of the general composition of the viral genome when a detailed information is not available. It consists in analyzing the restriction fragments generated by cleavage of the polymerase chain reaction (PCR) product with restriction endonucleases (ZHAO; BUEHRING, 2007). The $1,547 \mathrm{bp}$ env gene is the most used in this analysis, because it is the most variable and provides a general idea of the BLV genome, that is, $8,714 \mathrm{bp}$.

Several authors have reported the existence of six or seven genotypes of BLV by RFLP analysis, and some of them also mention the possible existence of a new genotype (RODRIGUEZ et al., 2009; MORATORIO et al., 2010; ABADNEH et al., 2012). A few also mention the classification of $B L V$ through phylogenetic analysis in two to four groups (CAMARGOS et al., 2007, HEMMATZADEH, 2007; MONTI et al., 2005; ZHAO; BUEHRING, 2007; JULIARENA et al., 2013;. LICURSI et al., 2003).

Considering many studies that have been carried out on the genetic variability of BLV and the lack of these studies in Santa Catarina state, the present investigation aimed to evaluate the existence of different genotypes of BLV in dairy cattle herds of the state, through genotyping by RFLP analysis. It is possible, through the identification of these genotypes, to determine the prevalence of viral genotypes in the four mesoregions analyzed and to establish a BLV profile in Santa Catarina state.

\section{MATERIALS E METHODS}

\section{Sample collection}

For the development of this work, visits were made to dairy cattle farms selected randomly between January 2012 and April
2013, distributed in four main mesoregions of the Santa Catarina state: the south, the sierra, the west and the north. Samples of 31 properties were obtained: eight cattle properties located in the north region, four properties in the western region, 12 properties in the south region, and seven properties in the region of the sierra of Santa Catarina. The animals sampled were mostly Holstein, Jersey and crossbred cattle used for milk production.

Blood samples were obtained from the caudal vein using siliconized vacuum tubes with clot activator (Labor Import, Osasco, São Paulo, Brazil) and ethylenediaminetetraacetic acid (EDTA) K3 anticoagulant (Vacuplast Collect Line, Nanchang, Jiangxi, China).

\section{Samples preparation}

Tubes containing blood with and without anticoagulant were subjected to centrifugation for 10 minutes at $403 \mathrm{xg}$ in a tabletop centrifuge (Janetzki T150, Engelsdorf, Leipzig, Germany).

The sera were then stored at $-20^{\circ} \mathrm{C}$ until the agar gel immunodiffusion test (AGID) was performed, and blood samples with anticoagulant were used to obtain the leukocyte layer, after centrifugation.

For the removal of erythrocytes, the white cell aspirate was washed with a solution of Tris EDTA pH 8, centrifuged at $2,000 \mathrm{xg}$, for five minutes in a MiniSpin centrifuge (Eppendorf, Hamburg, Germany) between each wash, totalizing averaged five washes or until the erythrocytes were removed as much as possible, and then stored in ultra-freezer $-80^{\circ} \mathrm{C}$ until the end of the AGID serological test, since proviral DNA extraction was performed only with samples from animals considered to be serologically positive.

\section{Serology by agar gel immunodiffusion}

The test was performed for the diagnosis of BLV through AGID, produced by Institute of Technology of Paraná (Instituto de Tecnologia do Paraná - TECPAR), in Curitiba, Brazil. The technique was performed following the manufacturer's recommendation.

Samples were considered positive when precipitation line was formed between the central well containing the antigen and the well with a serum sample tested, and also the identity line with the positive control serum.

Blood samples from seropositive animals were subjected to DNA extraction and PCR for amplification of the $440 \mathrm{bp}$ BLV env gene sequence.

\section{DNA extraction and amplification of bovine leukemia virus env gene by polymerase chain reaction}

To obtain the proviral DNA present in the leukocytes of the seropositive animals, the extraction was performed according 
to the protocol of TRI Reagent T9424 (Sigma-Aldrich, St. Louis, Missouri, United States).

After the extraction, a fragment of $440 \mathrm{bp}$ of $e n v$ gene was amplified by PCR technique, described by the OIEDIAGNOSTIC MANUAL (2012). The reaction mix was composed of $20 \mu \mathrm{L}$ of PCR Master Mix (Quatro G Ltda., Porto Alegre, Rio Grande do Sul, Brazil) and $1 \mu \mathrm{L}$ of each primer OBLV1A (5'-CTTTGTGTGCCAAGTCTCCCAGATACA-3 ') and OBLV6A (5' -CCAACATATAGCACAGTCTGGGAAGGC-3 ), and $3 \mu \mathrm{L}$ of the DNA sample. The final reaction volume was $25 \mu \mathrm{L}$.

The reaction conditions were $5 \mathrm{~min}$ at $94^{\circ} \mathrm{C}$, followed by five cycles at $94^{\circ} \mathrm{C}$ for $45 \mathrm{~s}, 60^{\circ} \mathrm{C}$ for $60 \mathrm{~s}$ and $72^{\circ} \mathrm{C}$ for $90 \mathrm{~s}$, followed by 35 cycles of $94^{\circ} \mathrm{C}$ for $45 \mathrm{~s}, 59^{\circ} \mathrm{C}$ for $60 \mathrm{~s}$ and $72^{\circ} \mathrm{C}$ for $90 \mathrm{~s}$. The last one was a cycle at $72^{\circ} \mathrm{C}$ for $7 \mathrm{~min}$.

The amplification products were then analyzed by $1.5 \%$ agarose gel electrophoresis, stained with a $0.5 \mu \mathrm{g} / \mathrm{mL}$ ethidium bromide solution.

\section{Polymerase chain reaction products analysis by restriction fragment length polymorphism}

This process consisted in the digestion of a fragment of the $440 \mathrm{bp}$ viral genome for 1 hour with $10 \mathrm{U}$ of restriction endonucleases BamHI (Promega, Madison, Wisconsin, United States) and HaeIII (Promega, Madison, Wisconsin, United States) at $37^{\circ} \mathrm{C}$; Tru9I (Promega, Wisconsin, United States) and TaqI (Promega, Wisconsin, United States) at $65^{\circ} \mathrm{C}$; and MwoI (New England Biolabs Inc., Ipswich, Massachussets, United States) at $60^{\circ} \mathrm{C}$.

After digestion of the samples, the electrophoresis was performed in a $3.5 \%$ agarose gel stained with ethidium bromide $0.5 \mu \mathrm{g} / \mathrm{mL}$.

The comparison method for classification of BLV genotypes was based on a table described by INOUE et al. (2011) relating the possible sizes of fragments formed after digestion with each restriction enzyme and the different combinations of these fragments that give rise to the seven different viral genotypes.

\section{RESULTS}

In the western region, 72 samples were collected in four properties, 13 of which were positive in serology. PCR of 11 samples showed nine positive, and in the genotyping two samples demonstrated the occurrence of genotype VIII. In the sierra region, 167 samples were collected in seven properties, being 114 positive in the serology. PCR of 36 samples showed 30 positive, and in the genotyping of eight samples the genotype II was found in two samples, genotype I in one sample, IX in one sample and $\mathrm{X}$ in four samples. In the southern region, 176 samples were collected in 12 properties, 51 of which were positive in serology and 21 in PCR, of 28 analyzed. In the RFLP analysis, eight samples were analyzed, genotype I was found in one sample, VIII in one sample, IX in two samples and X in four samples. Lastly, in the northern region, 39 samples were collected in eight regions, 13 of which were positive in the serology. The two samples analized by PCR were positive, and in the RFLP analysis, a sample of genotype $\mathrm{X}$ was found.

\section{Serology for enzootic bovine leukosis}

Through the serology of the 454 blood samples collected from 31 dairy cattle farms distributed in four regions of Santa Catarina state, 191 seropositive animals (42.1\%) were found and 21 properties with at least one seropositive animal (67.7\%).

In the western region, 72 animals were sampled in four properties, totalizing 13 seropositive animals, the lowest number of positive animals observed in the state. In the sierra region, 167 animals from seven properties were evaluated, which 114 animals were seropositive - the highest number of positivity in the state. In the southern region, 176 animals from 12 properties were sampled, totalizing 51 seropositive animals. In the northern region, 39 animals from eight properties were analyzed, and 13 were seropositive (Table 1).

\section{Bovine leukemia virus provirus detection by polymerase chain reaction technique}

Of the 191 serologically positive samples, PCR reaction was performed on 77 samples, and in 62 samples the fragment of interest of $440 \mathrm{bp}$ of the env gene was amplified (Fig. 1).

\section{Bovine leukemia virus classification by restriction fragment length polymorphism analysis of the env gene polymerase chain reaction products}

One amplicon of one sample from each property that presented BLV seropositive animals was digested by five restriction

Table 1. Relationship between collecting regions, performed analysis and results.

\begin{tabular}{lcc} 
Region & $\begin{array}{c}\text { AGID positives } \\
\mathbf{n}(\%)\end{array}$ & $\begin{array}{c}\text { PCR positives } \\
\mathbf{n}(\%)\end{array}$ \\
West & 18 & 81.8 \\
\hline Sierra & 68.3 & 83.3 \\
\hline South & 29 & 75 \\
\hline North & 33.4 & 100 \\
\hline Total & 42 & 80.5 \\
\hline
\end{tabular}

AGID: agar gel immunodiffusion; PCR: polymerase chain reaction. 
endonucleases - BamHI, HaeIII, Tru9I, TaqI and MwoI -, totaling 19 samples.

BamHI enzyme digestion showed two different cleavage patterns, one forming bands of 240 and $200 \mathrm{bp}$ and the other one forming only a band of $440 \mathrm{bp}$.

Digestion with the enzyme HaeIII cleaved all amplicons into five bands: 200, 90, 65, 35 and $25 \mathrm{bp}$.

In the Tru9I digestion, two different cleavage patterns were obtained: one forming two bands of 400 and $40 \mathrm{bp}$, observed in most of the samples; and one sample with cleavage in three bands, 270, 130 and $40 \mathrm{bp}$.

TaqI also showed two different patterns of cleavage: one formed two bands with size of 280 and $160 \mathrm{bp}$; and the other one with three bands of 230, 160 and $50 \mathrm{bp}$.

Three different cleavage patterns - one with three bands of 250, 160 and $30 \mathrm{bp}$; one with two bands of 280 and $160 \mathrm{bp}$; and a third one with three bands of 250, 100 and $90 \mathrm{bp}$ - were observed in the samples digested by the MwoI enzyme. These different cleavage patterns are described in Table 2.

Genotypes I and II identified in this study are consistent with previous findings described by INOUE et al. (2011). However, we identified three genotypes not yet described, classified as VIII, IX and X. These results indicate the existence of new variants of BLV circulating in Santa Catarina.

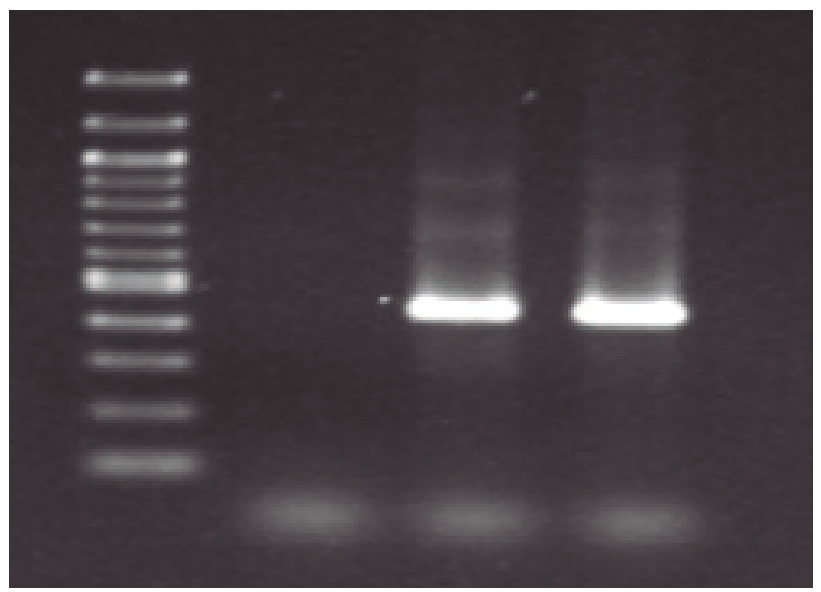

Figure 1. Amplification of the $440 \mathrm{bp}$ fragment of the env gene by the polymerase chain reaction technique.

\section{Prevalence of viral genotypes by restriction fragment length polymorphism analysis}

Genotype I presented the lowest prevalence (5\%): only one animal displayed it. For genotype II, two animals (11\%), genotype VIII, four animals (21\%), and genotype IX, three animals were identified (16\%), and genotype X showed the highest prevalence $(47 \%)$, with nine animals among the 19 tested.

Thus, it is worth mentioning that in this study we could observe that there are five circulating genotypes in Santa Catarina state, and the most prevalent genotype of them is $\mathrm{X}$.

\section{DISCUSSION}

In the present study, $42.1 \%(191 / 454)$ of the analyzed serum samples were positive for BLV. This result is different from the one found by MORAES et al. (1996), with only $12 \%$ of Rio Grande do Sul positive animals, CARVALHO et al. (1996), with 7\% in cattle from Londrina, Paraná state, and LUDERS (2001), with 7.6\% positive cattle in the northern region of Santa Catarina. Other authors, however, found similar results. BARROS FILHO et al. (2009) found prevalence of $56.3 \%$ in Curitiba, Paraná; CORDEIRO et al. (1994), of 35\% in Itajaí, Santa Catarina; D’ANGELINO et al. (1998), of 54\% in São Paulo; and RAJÃO (2008) in Minas Gerais found the highest prevalence $(79.7 \%)$, as did MONTI et al. (2005), with prevalence of $70 \%$ in the PCR and $90 \%$ in the AGID.

As for the prevalence of positive properties, 21/31 (67.7\%) were found, a rather high result when compared with the ones found by other authors such as MORAES et al. (1996) (29.1\%), CARVALHO et al. (1996) (35.7\%) and LUDERS (2001) (10.8\%).

In the positive samples, there was amplification through the PCR technique of a $440 \mathrm{bp}$ fragment of the env gene, as well as in the study by INOUE et al. (2011) and MATSUMURA

Table 2. Products generated by restriction enzyme cleavage of the $440 \mathrm{bp}$ fragment of the bovine leukemia virus env gene

\begin{tabular}{|c|c|c|c|c|c|}
\hline \multirow{2}{*}{ RFLP Type } & \multicolumn{5}{|c|}{ Restriction enzymes } \\
\hline & BamHI & Haelll & Tru9l & Taql & Mwol \\
\hline 1 & 240,200 & $200,90,65,35,25$ & $270,130,40$ & 280,160 & $250,160,30$ \\
\hline II & 240,200 & $200,90,65,35,25$ & 400,40 & 280,160 & $250,160,30$ \\
\hline VIII & 240,200 & $200,90,65,35,25$ & 400,40 & $230,160,50$ & 280,160 \\
\hline IX & 440 & $200,90,65,35,25$ & 400,40 & 280,160 & $250,160,30$ \\
\hline$x$ & 240,200 & $200,90,65,35,25$ & 400,40 & 280,160 & $250,100,90$ \\
\hline
\end{tabular}

RFLP: restriction fragment length polymorphism. 
et al. (2010) — both also amplified this fragment, corresponding to position 5029-5468 of the viral genome.

In this study, PCR products from the env gene were submitted to enzymatic restriction analysis with restriction endonucleases, similar to the study by INOUE et al. (2011), who also used the same enzymes, except Tru9I. MseI enzyme was used instead, but both have the same cleavage site.

In the present investigation, two different cleavage patterns were observed for the $440 \mathrm{bp}$ fragment by BamHI enzyme, one forming two sizes of bands, of 240 and $200 \mathrm{bp}$ found in genotypes I, II, VIII, X; and the other one only a band of $440 \mathrm{bp}$. That is, the fragment was not cleaved, being found in genotype IX. These findings were similar to those established by INOUE et al. (2011), who observed only a cleavage pattern, with bands of 240 and $200 \mathrm{bp}$, in tumor samples, thus not being the definitive standard for genotyping.

The cleavage of the amplicons with the enzyme HaeIII gave rise to five fragments of $200,90,65,35$ and $25 \mathrm{bp}$. This pattern was not definitive for genotyping, because it was found in all genotypes, matching the pattern also found by INOUE et al. (2011), which further identified a different cleavage pattern, forming four bands with sizes of 290, 65, 35, and $25 \mathrm{bp}$ for the $440 \mathrm{bp}$ fragment.

The Tru9I enzyme, obtained two different cleavage patterns, one forming two bands of 400 and $40 \mathrm{bp}$, was observed in most of the samples, and one sample with cleavage in three bands, 270, 130 and $40 \mathrm{bp}$, was seen, in agreement with the findings of INOUE et al. (2011). However, these authors still found a third pattern, with bands of 360 and $40 \mathrm{bp}$.

The TaqI also presented two different cleavage patterns, one forming two bands with size of 280 and $160 \mathrm{bp}$ and the other one with three bands of 230, 160 and $50 \mathrm{bp}$. INOUE et al. (2011) also found these two cleavage patterns and a third one, with bands of 240,160 and $40 \mathrm{bp}$.

The samples that were digested by the MwoI enzyme presented three different cleavage patterns: one with three bands of 250, 160 and $30 \mathrm{bp}$, another one with two bands of 280 and $160 \mathrm{bp}$, and the last one with three bands of 250 , 100 and $90 \mathrm{bp}$, in agreement with the findings of INOUE et al. (2011), but we also found a third pattern with three bands of 250, 100 and $90 \mathrm{bp}$, not described by the aforementioned authors.

In this study, we could observe five circulating genotypes in the analyzed samples of dairy cattle in Santa Catarina. Among them, the genotypes I and II described by INOUE et al. (2011) in Japan, which identified a total of seven BLV genotypes by RFLP analysis of the $440 \mathrm{bp}$ fragment of the env gene, from bovine tumor samples using restriction enzymes with the same restriction site used in this study. Seven BLV genotypes were also identified by
MORATÓRIO et al. (2010) through sequencing and phylogenetic analysis of bovine blood samples from Uruguay, and by BALIC et al. (2012) and MATSUMURA et al. (2010), carrying out a sequential and phylogenetic analysis of $356 \mathrm{bp}$ fragment of the env gene from bovine blood samples in Croatia and tumors in Japan, also observed a new genotype.

Through sequencing and phylogenetic analysis of the $e n v$ gene of bovine samples from Argentina, RODRIGUEZ et al. (2009) identified six genotypes, as well as LICURSI et al. (2002), and proposed the existence of a seventh genotype, similar to previous findings. CAMARGOS et al. (2007) observed in cattle of the Brazilian states of Paraná, Minas Gerais, Mato Grosso do Sul e Goiás and ABADNEH et al. (2012) in Jordanian dairy cattle by the RFLP analysis of a $444 \mathrm{bp}$ fragment of the env gene with restriction enzymes, the presence of genotype I, also found in this study, and genotype VI, which was not found to be circulating in Santa Catarina. MONTI et al. (2005) through RFLP analysis also found two genotypes, classified as Australian and Argentine.

Among the five genotypes found - I, II, VIII, IX, X-, genotype I has already been described by MORATÓRIO et al. (2010), which detected the genotypes V, VI, and VII in Brazilian samples, similar to those obtained by CAMARGOS et al. (2007) in Paraná, Minas Gerais, Mato Grosso do Sul e Goiás samples, also finding genotypes I and VI.

Genotype X, so named because it did not fit into any of the genotypes described, was the most prevalent among the analyzed samples, followed by genotypes VIII, IX, II and I, disagreeing with results found by MATSUMURA et al. (2010), who identified the highest prevalence of genotype I through phylogenetic analysis of bovine tumors in Japan. However, these authors described the presence of two major viral populations in the country.

As for the predominance of viral genotypes by region of the state, it is worth mentioning that among genotypes the genotype $\mathrm{X}$ was found in the north, south and sierra, being absent in the western region. Genotype IX was found in the southern and sierra regions. Genotype VIII was present in the south and west regions, and genotype I was restricted to the southern region, as well as the genotype II to the sierra. These findings corroborate with RODRIGUEZ et al. (2009), who reported that there is a limited group of genotypes, which are distributed irregularly.

Due to the scarcity of studies on the variability of BLV in Santa Catarina, it is of great importance to identify some of the circulating genotypes, as well as the detection of new genotypes and their prevalence. With this data, it is possible to trace infections caused by different genotypes of BLV, and identify the introduction of new viruses from other states or countries. Considering that Santa Catarina is a disease-free 
area such as foot-and-mouth disease, this type of screening is extremely relevant and necessary.

It is known that the development of retrovirus vaccines is extremely difficult because of the constant genetic variation of the agent. However, identifying BLV genotypes can be an important step in trying to develop vaccines that cover the most prevalent samples in a particular region or herd.

\section{CONCLUSIONS}

There are at least five BLV genotypes circulating in Santa Catarina state, and these genotypes are distributed in the analyzed mesoregions.

Among the genotypes identified, three were not previously described, and one of them, classified as genotype $\mathrm{X}$, was the most prevalent among the analyzed samples.

| | | | | | | | | | | | | | | | | | | | | | | | | | | | | | | | | | | | | | | | | | | | | | | | | | | | | | | | | | | | | | | | | | | | | | | | | | | | | | | | | | | | | | | | | | | | | | | | | | | | | | | | | | | | | | | | | | | | | | | | | | | | | | | | | | | | | | | | | | | | | | | | | | | | | | | | | | | | | | | | | | | | | | | | | | | | | | | | | | | | | | | | | | | | | | | | | | | | | | | | | | | | | | | | | | | | | | | | | | | | REFERENCES

ABADNEH, M.M.; AL-RUKIBAT, R.K.; HANANEH, W.M.; NASAR, A.T.; AL-ZGHOUL, M.B. Detection and molecular characterization of bovine leukemia viruses from Jordan. Archives of Virology, Austria, v.157, n.12, p.2343-2348, 2012.

BALIC, D.; LOJKIC, I.; PERISKIC, M.; BEDEKOVIC, T.; JUNGIC, A.; LEMO, N.; ROIC, B.; CAC, Z.; BARBIC, L.; MADIC, J. Identification of a new genotype of bovine leukemia virus. Archives of Virology, Austria, v.157, n.7, p.1281-1290, 2012.

BARROS FILHO, I.R.; GUIMARÃES, A.K.; BIONDO, A.W.; KRÜGER, E.R.; WAMMES, E.V.; OLLHOFF, R.D.; PIEKARZ, C.H.; SPONCHIADO, D. Prevalência da Leucose enzoótica em bovinos leiteiros criados na região metropolitana de Curitiba - Paraná. Ciência Animal Brasileira, Goiânia, p. 11-14, 2009.

CAMARGOS, M.F.; PEREDA, A.; STANCEK, D.; ROCHA, M.A.; DOS REIS, J.K.P.; GREISER-WILKE, I.; LEITE, R.C. Molecular characterization of the env gene from Brazilian field isolates of Bovine Leukemia Virus. Virus genes, [s.I.], v.34, n.3, p.343350, 2007.

CANN, A.J. Principles of Molecular Virology. 4 ed. Estados Unidos: Elsevier Academic Press, 2005. 332p.

CARVALHO, L.; BENESI, F. J.; BIRGEL JUNIOR, E.H.; BIRGEL, E.H. Prevalência de anticorpos séricos de anti-vírus da leucose dos bovinos em animais da raça Holandesa Preta e Branca e zebuínos da raça Nelore, criados no pólo regional de Londrina, Estado do Paraná. Semina: Ciências Agrárias, Londrina, v.17, n. 1, p.53-57, 1996.

CORDEIRO, J.L.F.; DESCHAMPS, F.C.; MARTINS, E.; MARTINS, V.M.V. Identificação e controle da leucose enzoótica bovina (LEB) em um rebanho leiteiro. Pesquisa Agropecuária Brasileira, Brasília, v.29, n.8, p.1287-1292, 1994.

D'ANGELINO, J.L.; GARCIA, M.; BIRGEL, E.H. Epidemiological study of enzootic bovine leukosis in Brazil: Short Comunication. Tropical AnimalHealth and Production, Amsterdam, v.30, n.1, p.13-15, 1998.

HEMMATZADEH, F. Sequencing and phylogenetic analysis of gp5 1 gene of bovine leukaemia virus in Iranian isolates. Veterinary Research Communications, Holanda, v.31, n.6, p.783-789, 2007.
INOUE, E.; MATSUMURA, K.; MAEKAWA, K.; NAGATSUKA, K.; NOBUTA, M.; HIRATA, M.; MINAGAWA, A.; OSAWA, Y.; OKAZAKI, $K$. Genetic heterogeneity among bovine leukemia viruses in Japan and their relationship to leukemogenicity. Archives of Virology, Austria, v.156, n.7, p.1137-114, 2011.

JULIARENA, M.A.; LENDEZ, P.A.; GUTIERREZ, S.E.; FORLETTI, A.; RENSETTI, D.E.; CERIANI, M.C. Partial molecular characterization of different proviral strains of bovine leukemia virus. Archives of Virology, Austria, v. 158, n. 1, p.63-70, 2013.

LEUZZI JR, L.A.; ALFIERI, A. F.; ALFIERI, A.A. Leucose enzoótica bovina e vírus da leucemia bovina. Semina: Ciências Agrárias, Londrina, v.22, n.2, p.211-221, 2001.

LICURSI, M.; INOSHIMA, Y.; WU, D.; YOKOYAMA, T.; GONZÁLEZ, E.T.; SENTSUI, H. Genetic heterogeneity among bovine leukemia virus genotypes and its relation to humoral responses in hosts. Virus Research, Philadelphia, v. 86, n. 1-2, p. $101-110,2002$.

LICURSI, M.; INOSHIMA, Y.; WU, D.; YOKOYAMA, T.; GONZÁLEZ, E.T.; SENTSUI, H. Provirus variants of bovine leukemia virus in naturally infected cattle from Argentina and Japan. Veterinary Microbiology, [s.l.], v.96, n.1, p.17-23, 2003.

LUDERS, M.A. Prevalência de anticorpos contra o vírus da leucose enzoótica bovina em fêmeas com mais de dois anos no Rebanho de bovinos leiteiros no Município de Mafra-SC. 2001, 30f. Dissertation (Master in Agroveterinary Sciences / Animal Sanity) - Universidade do Estado de Santa Catarina, Lages, 2001.

MATSUMURA, K.; INOUE, E.; OSAWA, Y.; OKAZAKI, K. Molecular epidemiology of bovine leukemia virus associated with enzootic bovine leukosis in Japan. Virus research, Philidelphia, v. 155, n. 1, p.343-348, 2011.

MONTI, G.; SCHRIJVER, R.; BEIER, D. Genetic diversity and spread of Bovine leukaemia virus isolates in Argentine dairy cattle. Archives of Virology, Austria, v. 150, n.3, p.443-448, 2005.

MORAES, M.P.; WEIBLEN, R.; FLORES, E.F.; OLIVEIRA, J.C.D.; REBELATTO, M.C.; ZANINI, M.; RABUSKE, M.; HÜBNER, S.O.; PEREIRA, N.M. Levantamento sorológico da infecção pelo vírus da Leucose Bovina nos rebanhos leiteiros do Estado do Rio Grande do Sul, Brasil. Ciência Rural, Santa Maria, v.26, n.2, p.257-262, 1996. 
MORATORIO, G.; OBAL, G.; DUBRA, A.; CORREA, A.; BIANCHI, S.; BUSCHIAZZO, A.; CRISTINA, J.; PRITSH, O. Phylogenetic analysis of bovine leukemia viruses isolated in South America reveals diversification in seven distinct genotypes. Archives of Virology, Austria, v.155, n.4, p.481-489, 2010.

OIE, Terrestrial Manual. Enzootic Bovine Leukosis, cap. 2.4.11, p. 1-11. Available from: <http://www.oie.int/fileadmin/Home/ eng/Health_standards/tahm/2008/pdf/2.04.11_EBL.pdf $>$. Accessed on: Jul. 162014.

RAJÃO, D.S. Efeito da infecção pelo vírus da Leucose Enzoótica Bovina na produção de leite e reprodução de rebanhos leiteiros. 2008, 26f. Dissertation (Master of Animal Science / Preventive
Veterinary Medicine) - Escola de Veterinária da Universidade Federal de Minas Gerais, Belo Horizonte, 2008.

RODRIGUEZ, S.M.; GOLEMBA, M.D.; CAMPOS, R.H.; TRONO, K.; JONES, L.R. Bovine leukemia virus can be classified into seven genotypes: evidence for the existence of two novel clades. Journal of General Virology, [s.l.], v.90, p.2788-2797, 2009.

TOSTES, R.A. Situação da Leucose Bovina no Brasil: uma revisão. Colloquium Agrariae, Presidente Prudente, v. 1, n. 1, p.42-50, 2005.

ZHAO, X.; BUEHRING, G.C. Natural genetic variations in bovine leukemia virus envelope gene: possible effects of selection and escape. Virology, Amsterdam, v.366, n.1, p.150-165, 2007. 